\title{
REKOMENDASI ARTIKEL MENGGUNAKAN ALGORITMA APRIORI PADA WEBSITE
}

\author{
Ivan Yusuf Rahadika ${ }^{1}$, Amak Yunus Eko Prasetyo ${ }^{2}$, Moh. Ahsan ${ }^{3}$ \\ Teknik Informatika, Universitas Kanjuruhan Malang 1,2,3

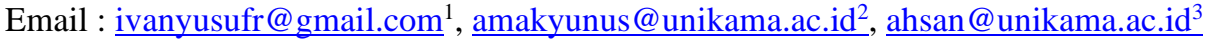

\begin{abstract}
Abstrak. Website adalah kumpulan halaman-halaman situs yang menampilkan banyak macam artikel yang menarik dan bermanfaat bagi pengunjung. Art7wing merupakan salah satu website yang fokus pada informasi teknologi dan hiburan, yang hanya menampilkan artikel yang baru dipublish, sehingga banyak artikel yang memiliki kesempatan sedikit untuk dikunjungi. Algoritma Apriori merupakan data mining yang digunakan untuk menanmpilkan rekomendasi artikel. Penelitian ini bertujuan untuk mengetahui penggunaan algoritma Apriori dalam memberikan rekomendasi artikel pada website Art7wing. Hasil penelitian menunjukkan bahwa algoritma Apriori dapat menampilkan rekomendasi artikel. Terbukti dengan berhasilnya rekomendasi artikel yang tampil pada halaman artikel website Art7wing.
\end{abstract}

Kata Kunci: Website; PHP; algoritma apriori

\section{PENDAHULUAN [tanpa judul subbab]}

Website adalah kumpulan halaman situs yang biasanya terkumpul dalam domain atau subdomain, berada didalam World Wide Web (WWW) di Internet. Umumnya pada sebuah halaman website menampilkan banyak macam konten yang menarik dan bermanfaat bagi pengunjung. Tetapi banyaknya konten tersebut dapat mempengaruhi kebutuhan ruang pada halaman website. Disamping itu, kebanyakan sebuah website informasi menampilkan banyak sekali konten artikel yang diurutkan berdasarkan tanggal publikasi. Art7wing adalah website yang berfokus pada informasi teknologi dan hiburan. Tujuannya adalah memberikan informasi dan inspirasi kepada pengunjung. Pengelola website tersebut terdiri dari dua orang, sehingga artikel yang disajikan sangat sedikit. Sama seperti website lainnya, Art7wing menampilkan artikel yang baru saja di publish, sehingga banyak artikel yang memiliki sedikit kesempatan untuk dikunjungi.

Untuk mengatasi masalah ini, maka timbul upaya untuk penampilan tautan yang direkomendasikan kepada pengunjung. Sehingga menciptakan kesempatan artikel lain dibaca oleh pengunjung. Salah satu teknik yang dapat diterapkan untuk menyelesaikan masalah ini yaitu algoritma Apriori. Algoritma Apriori dapat dikategorikan dalam jenis aturan asosiasi pada data mining. Aturan ini sering sering disebut affinity analysis atau market basket analysis karena menyatakan asosiasi antara beberapa atribut. Untuk menemukan aturan asosiatif antara suatu kombinasi item menggunakan teknik analisis asosiasi atau association rule mining. Aturan asosiatif dianggap penting dengan melihat nilai support dan confidence. Support (nilai penunjang) adalah nilai persentase kombinasi item muncul dalam database, sedangkan confidence (nilai kepastian) adalah kuatnya keterkaitan item-item dari aturan asosiasi (Kusrini dan Lutfi, 2009). Penggunaan algoritma Apriori ditujukan untuk menemukan aturan asosiasi dalam rekomendasi artikel website Art7wing yaitu menambang keterhubungan antara item-item yang terkandung dalam data riwayat kunjungan. Sehingga penelitian ini bertujuan untuk mengetahui implementasi algoritma apriori dalam memberikan rekomendasi artikel pada 
halaman website Art7wing. Ruang lingkup dan batasan masalah pada penelitian ini adalah memberikan beberapa tautan rekomendasi artikel pada halaman website Art7wing dengan algoritma Apriori, bahasa pemrograman menggunakan PHP, jumlah data riwayat baca 6000 data selama dua bulan terakhir.

\section{METODE PENELITIAN}

\section{Metode Penelitian Pengembangan}

Model pengembangan penelitian ini adalah dengan menggunakan model Research and Development atau dapat diartikan sebagai penelitian dan pengembangan. Pengembangan produk dapat berupa memperbaiki produk yanng telah ada sehingga dapat membuat produk yang praktis, efektif dan efisien. Pengembangan juga dapat menghasilkan produk baru yang belum pernah ada (Sugiyono, 2016). Model pengembangan Multimedia Development Life Cycle (MDLC) versi Luther terdiri dari 6 tahap, yaitu concept, design, material collecting, assembly, testing dan distribution. Dalam prakteknya keenam tahap ini tidak harus berurutan, posisi tahaptahap tersebut dapat ditukat. Namun tahap konsep harus dikerjakan pertama kali (Sutopo, 2012).Untuk pengembangan sistem ini menggunakan model MDLC tersebut. MDLC memiliki beberapa kelebihan (Binanto, 2013), antara lain : (a) Mudah dimengerti dan diimplementasikan, (b) Tahapannya jelas dan mudah dikuti, (c) Terstruktur dan berurut secara logis, (d) Dapat digunakan oleh pengembang kecil

\section{Prosedur Penelitian Pengembangan}

Pada pengembangan peneliti menggunakan model MDLC yang sering digunakan dalam pengembangan aplikasi mutimendia. Model ini terbagi atas:

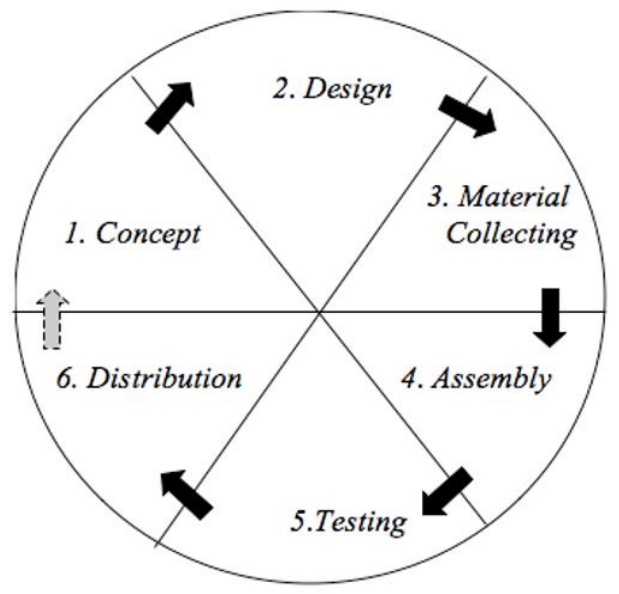

Gambar 1. Metode MDLC (Sutopo, 2012)

Concept (Konsep)

Tahap concept (konsep) menggambarkan pengembangan website mengenai deskripsi, tujuan pengembangan, dan bagaimana mencapai tujuan pengembangan website. Dengan konsep tersebut dapat digunakan untuk mengembangkan website yang memiliki rekomendasi artikel. Tahap ini menjadi dasar dalam pengembangan website Art7wing oleh peneliti.

Design (Perancangan)

Tahap ini adalah tahap pembuatan spesifikasi mengenai arsitektur website, tampilan dan kebutuhan material atau bahan untuk program, dan penerapan algoritama Apriori untuk memberikan rekomendasi artikel. Dalam desain ini peneliti akan mendesain pengoperasian website dari awal website dibuka sampai user mendapat rekomendasi artikel. 


\section{Material Collecting (Pengumpulan Bahan)}

Tahap ini adalah tahap pengumpulan bahan untuk memenuhi kebutuhan yang dikerjakan. Bahan-bahan yang dikumpulkan antara lain gambar, teks dan lain-lain yang dapat diperoleh secara gratis atau dengan membuat sendiri dengan software pendukung.

Assembly (Perkaitan)

Tahap assembly atau perakitan adalah tahap perakitan bahan-bahan yang digunakan untuk mengembangkan website sehingga menjadi website yang dapat memberikan rekomendasi artikel dengan menggunakan aturan asosiasi yang dihasilkan algoritma Apriori.

Testing (Pengujian)

Pada tahap pengujian ini, perangkat lunak yang proses pengkodeannya sudah selesai akan di ujikan untuk memastikan semua bagian sudah berfungsi. Hal ini dikerjakan untuk memperkecil munculnya kesalahan dan memastikan keluaran pereangkat lunak sesuai dengan yang diinginkan.

\section{Distribution (Distribusi)}

Tahap ini aplikasi yang dikembangkan akan disimpan dalam suatu media penyimpanan sehingga bisa dijangkau oleh user. Dalam penelitian ini, proses distribusi ini meliputi proses upload ke virtual server. Penyimpanan website dalam bentuk folder dan file, dengan berbagai bentuk hak akses untuk menjaga keamanan dan pengembangan website.

\section{Algoritma Apriori}

Algoritma ini mengendalikan berkembangnya kandidat itemset dan hasil Frequent itemsets menggunakan support-based pruning untuk mendapatkan itemset yang menarik dengan menetapkan minimum support (Fadlina, 2014).

Algoritma Apriori dapat dikategorikan dalam jenis aturan asosiasi pada data mining. Aturan ini sering sering disebut affinity analysis atau market basket analysis karena menyatakan asosiasi antara beberapa atribut. Untuk menemukan aturan asosiatif antara suatu kombinasi item menggunakan teknik analisis asosiasi atau association rule mining. Aturan asosiatif dianggap penting dengan melihat nilai support dan confidence. Support (nilai penunjang) adalah nilai persentase kombinasi item muncul dalam database, sedangkan confidence (nilai kepastian) adalah kuatnya keterkaitan item-item dari aturan asosiasi (Kusrini dan Lutfi, 2009).

Definisi analisis asosiasi yaitu suatu proses untuk mendapatkan semua aturan asosiasi yang memenuhi nilai minimum untuk support (minimum support) dan nilai minimum untuk confidence (minimum confidence). Metodologi dasar analisis asosiasi terbagi menjadi dua tahap:

\section{Analisis Pola Frekuensi Tertinggi}

Dalam tahap ini dilakukan pencarian kombinasi item yang memenuhi syarat minimum dari nilai support dalam database. Nilai support dari item diperoleh menggunakan persamaan berikut:

Support $(A)=\frac{\sum \text { Transaksi mengandung } A}{\sum \text { Transaksi }} \frac{\sum \text { TransaksimengandungA }}{\sum \text { Transaksi }}$

Sementara itu, nilai support dari 2 item diperoleh menggunakan persamaan 2 berikut.

Support $(A, B)=P(A \cap B)$

Support $(A, B)=\frac{\sum \text { Transaksi mengandung } A \text { dan } B}{\sum \text { Transaksi }}$

\section{Pembentukan Aturan Asosiasi}

Setelah mendapatkan semua pola frekuensi tinggi, barulah mencari aturan asosiasi yang memenuhi nilai minimum untuk confidence dengan menghitung confidence aturan asosiatif $\mathrm{A} \Rightarrow$ B.

Nilai confidence dari aturan $\mathrm{A} \Rightarrow \mathrm{B}$ diperoleh menggunakan persamaan berikut.

Confidence $=P(B \mid A)$ 
Confidence $=\frac{\sum \text { Transaksi mengandung A dan B }}{\sum \text { Transaksi mengandung } A}$

\section{HASIL DAN PEMBAHASAN}

\section{Perancangan Algoritma Apriori}

Rancangan algoritma Apriori pada web yang dikembangkan, yaitu gambaran penerapan algoritma Apriori untuk menghasilkan rekomendasi artikel menggunakan riwayat kunjungan artikel. Proses yang dilakukan pertama kali, yaitu mengambil data riwayat kunjungan.

Tabel 1 Data Riawayat Kunjungan

\begin{tabular}{cl}
\hline Pengunjung & Kategori Item Artikel \\
\hline 1 & News, Musik, Game, Komputer, Teknologi, Linux, Hiburan, Sosial \\
\hline 2 & Game, News \\
\hline 3 & Game, News \\
\hline 4 & Game, News \\
\hline 6 & Game, Teknologi, News, Sosial \\
\hline 7 & Teknologi, News, Linux \\
\hline 8 & Musik, Game, Komputer, News \\
\hline 9 & News, Game, Sosial, Teknologi, Musik \\
\hline 10 & Lusik, News, Game \\
\hline
\end{tabular}

Tabel 2 Format Tabular Riwayat Kunjungan

\begin{tabular}{c|c|c|c|c|c|c|c|c}
\hline Pengunjung & News & Musik & Game & Komputer & Teknologi & Linux & Hiburan & Sosial \\
\hline 1 & 1 & 1 & 1 & 1 & 1 & 1 & 1 & 1 \\
\hline 2 & 1 & 0 & 1 & 0 & 0 & 0 & 0 & 0 \\
\hline 3 & 1 & 0 & 1 & 0 & 0 & 0 & 0 & 0 \\
\hline 4 & 1 & 0 & 1 & 0 & 0 & 0 & 0 & 0 \\
\hline 5 & 1 & 0 & 1 & 0 & 1 & 0 & 0 & 1 \\
\hline 6 & 1 & 0 & 0 & 0 & 1 & 1 & 0 & 0 \\
\hline 7 & 1 & 1 & 1 & 1 & 0 & 0 & 0 & 0 \\
\hline 8 & 1 & 1 & 1 & 0 & 1 & 0 & 0 & 1 \\
\hline 9 & 1 & 1 & 1 & 0 & 0 & 0 & 0 & 0 \\
\hline 10 & 1 & 0 & 1 & 0 & 0 & 1 & 0 & 0 \\
\hline
\end{tabular}

Untuk menerapkan algoritma Apriori terbagi dalam tahap analisa pola frekuensi tertinggi dan tahap pembentukan aturan asosiasi. Iterasi dilakukan terhadap perkembangan banyaknya kombinasi item dari calon itemset. Untuk melakukan tahap analisa pola frekuensi tertinggi, ditentukan minimum support untuk menemukan itemset frekuen.

Tabel 3 Calon 1-itemset

\begin{tabular}{ll}
\hline \multicolumn{1}{c}{ Item } & Support \\
\hline News & $10 / 10100 \%$ \\
\hline Musik & $4 / 1040 \%$ \\
\hline Game & $9 / 1090 \%$ \\
\hline Komputer & $2 / 1020 \%$ \\
\hline Teknologi & $4 / 1040 \%$ \\
\hline Linux & $3 / 1030 \%$ \\
\hline Hiburan & $1 / 1010 \%$ \\
\hline Sosial & $3 / 1030 \%$ \\
\hline
\end{tabular}


Pada calon 1-itemset tidak dilakukan kombinasi item, item didapat dari semua ketegori artikel yang muncul pada data riwayat kunjungan seperti tampak pada Tabel 1. Kemudian dihitung nilai support pada setiap item dengan persamaan (1). Contohnya pada item Komputer, nilai support berasal dari jumlah munculnya Komputer satu kali pada setiap pengunjung yaitu 2 dibagi jumlah pengunjung yaitu 10, hasilnya 0.2 atau 20\%. Misalkan ditentukan minimum support adalah $40 \%$ maka itemset frekuen $\left(F_{1}\right)$ yaitu \{News, Musik, Game, dan Teknologi\}.

Tabel 4 Calon 2-itemset

\begin{tabular}{ccc}
\hline \multicolumn{2}{c}{ Kombinasi Kategori Item Artikel } & \multirow{2}{*}{ Support } \\
\cline { 1 - 2 } $\mathrm{A}$ & $\mathrm{B}$ & \\
\hline News & Musik & $4 / 1040 \%$ \\
\hline News & Game & $9 / 1090 \%$ \\
\hline News & Teknologi & $4 / 1040 \%$ \\
\hline Musik & Game & $4 / 1040 \%$ \\
\hline Musik & Teknologi & $2 / 1020 \%$ \\
\hline Game & Teknologi & $3 / 1030 \%$ \\
\hline
\end{tabular}

Pada calon 2-itemset dan seterusnya seperti tampak pada Tabel 4, item calon itemset didapat dari itemset frekuent pada calon itemset sebelumnya dan untuk menghitung nilai support menggunakan persamaan (2). Item calon itemset dikombinasikan menjadi item antecedent A dan consequent B. Contoh untuk menghitung nilai support pada item Musik dan Game, nilai support berasal dari jumlah munculnya Musik dan Game bersamaan satu kali pada setiap pengunjung yaitu 4 dibagi jumlah pengunjung yaitu 10, hasilnya 0.4 atau $40 \%$. Dengan menetapkan minimum support maka itemset frekuen $\left(F_{2}\right)$, yaitu $\{\{$ News, Musik $\},\{$ News, Game\}, \{News, Teknologi\}, dan \{Musik, Game\}\}.

Tabel 5 Calon 3-itemset

\begin{tabular}{lll}
\hline \multicolumn{2}{c}{ Kombinasi Kategori Item Artikel } & Support \\
\cline { 1 - 2 } A & \multicolumn{1}{c}{ B } & \\
\hline News, Musik & Game & $4 / 1040 \%$ \\
\hline News, Musik & Teknologi & $2 / 1020 \%$ \\
\hline News, Game & Teknologi & $3 / 1030 \%$ \\
\hline Musik, Game & Teknologi & $2 / 1020 \%$ \\
\hline
\end{tabular}

Pada calon 3-itemset dengan menetapkan minimum support maka itemset frekuen atau $\left(F_{3}\right)$, yaitu \{News, Musik, Game\} seperti tampak pada Tabel 5. Contoh untuk menghitung nilai support pada item \{News, Musik\} dan \{Teknologi\}, nilai support berasal dari jumlah munculnya News, Musik dan Teknologi bersamaan satu kali pada setiap pengunjung yaitu 2 dibagi jumlah pengunjung yaitu 10, hasilnya 0.2 atau $20 \%$. Karena jumlah item dari itemset frekuen tidak mencukupi untuk calon 4-itemset maka iterasi berhenti.

Pada tahap pembentukan aturan asosiasi dibentuk calon aturan asosiasi $\mathrm{A} \Rightarrow \mathrm{B}$, sehingga dibutuhkan item dari itemset frekuen yang telah ditemukan untuk menjadi item antecedent $\mathrm{A}$ dan item consequent B. Aturan asosiasi dibentuk dari calon aturan asosiasi yang memenuhi syarat minimum untuk confidence. Untuk menghitung nilai confidence calon aturan asosiasi menggunakan persamaan (3).

Calon aturan asosiasi yang dibentuk dari $F_{2}$ seperti tampak pada Tabel 6. Contoh untuk menghitung nilai confidence pada aturan "Jika News, Game, dan Teknologi, maka Musik", nilai confidence berasal dari jumlah munculnya item antecedent $\{$ News, Game, Teknologi $\}$ dan item consequent \{Musik\} bersamaan satu kali pada setiap pengunjung yaitu 4 dibagi jumlah item antecedent yaitu 3 , hasilnya 0.666 atau $66.6 \%$. Misalkan ditetapkan minimum confidence adalah $90 \%$ maka aturan asosiasi yang dapat dibentuk, yaitu "Jika Musik, Game, dan Teknologi, maka News" dan "Jika News, Musik, dan Teknologi, maka Game". 
Tabel 6. Calon Aturan Asosiasi dari F2

\begin{tabular}{ll}
\hline \multicolumn{1}{c}{ Aturan } & Confidence \\
\hline Jika Musik, Game, dan Teknologi, maka News & $2 / 2100 \%$ \\
\hline Jika News, Game, dan Teknologi, maka Musik & $2 / 366.6 \%$ \\
\hline Jika News, Musik, dan Teknologi, maka Game & $2 / 2100 \%$ \\
\hline Jika News, Musik, dan Game, maka Teknologi & $2 / 450 \%$ \\
\hline
\end{tabular}

Tabel 7. Calon Aturan Asosiasi dari F3

\begin{tabular}{ll}
\hline \multicolumn{1}{c}{ Aturan } & \multicolumn{1}{c}{ Confidence } \\
\hline Jika Musik dan Game, maka News & $4 / 4100 \%$ \\
\hline Jika News dan Game, maka Musik & $4 / 944.444444444444 \%$ \\
\hline Jika News dan Musik, maka Game & $4 / 4100 \%$ \\
\hline
\end{tabular}

Calon aturan asosiasi yang dibentuk dari $F_{3}$ seperti tampak pada Tabel 7. Contoh untuk menghitung nilai confidence pada aturan "Jika Musik dan Game, maka News", nilai confidence berasal dari jumlah munculnya item antecedent \{Musik, Game\} dan item consequent \{News bersamaan satu kali pada setiap pengunjung yaitu 4 dibagi jumlah item antecedent yaitu 4, hasilnya 1 atau $100 \%$. Dengan menetapkan minimum confidence maka aturan asosiasi yang dapat dibentuk, yaitu "Jika Musik dan Game, maka News" dan "Jika News dan Musik, maka Game". Misalkan pengunjung mengunjungi artikel dengan kategori News, maka aturan asosiasi dengan item consequent bernilai News akan disimpan. Aturan asosiasi yang terakhir disimpan, item antecedent-nya dijadikan rekomendasi kategori artikel. Sehingga rekomendasi artikel untuk kategori News diambil dari aturan asosiasi yang terbentuk dari $F_{3}$, yaitu "Jika Musik dan Game, maka News". Maka rekomendasi kategori artikel, yaitu Musik dan Game.

\section{Perancangan UML (Sistem)}

Perancangan web ini menggunakan Unified Model Language (UML) sebagai pemodelan sistem, adapun diagram-diagram yang dirancang berurutan di dalam Unified Model Language (UML) adalah:

\section{a. Activity Diagram}

Berbagai alur aktivitas dalam sistem yang sedang dirancang digambarkan dalam bentuk Activity diagram. Activity diagram pada web yang akan dikembangkan yaitu activity diagram kunjungan halaman artikel. Dapat dilihat pada Gambar 2 dibawah ini:

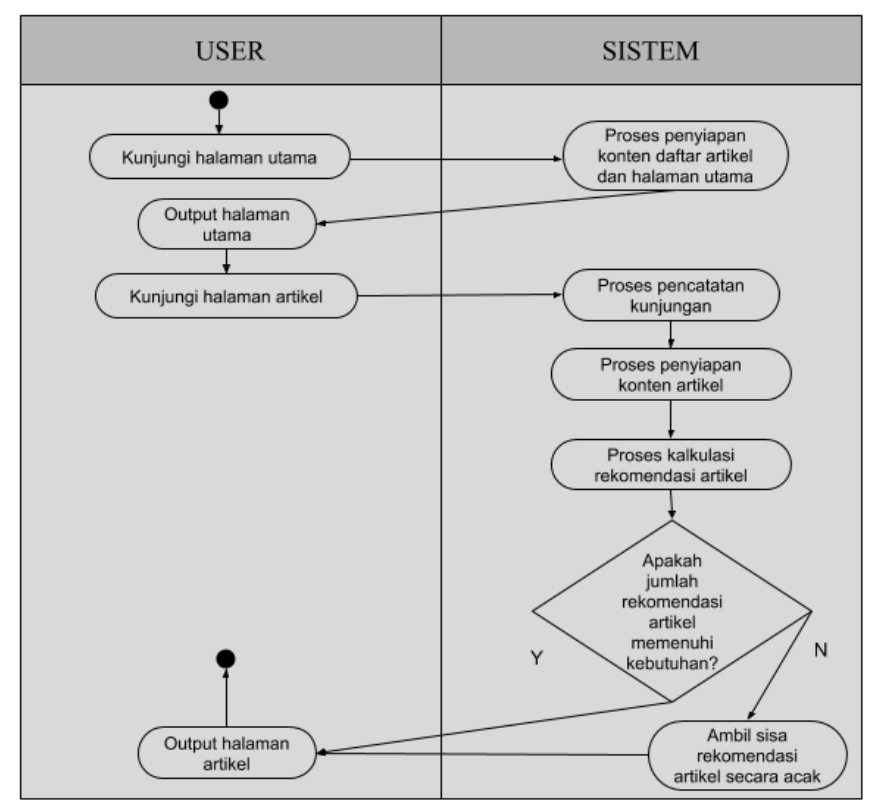

Gambar 2 Activity Diagram Mengunjungi Halaman Artikel 
Pada activity diagram Gambar 2 alur kerjanya dimulai dari start kemudian melakukan kunjungan pada halaman utama. Setelah itu, melakukan kunjungan terhadap halaman artikel melalui tautan artikel pada halaman utama. Kemudian sistem akan menerima data identitas pengunjung dan identitas artikel yang hendak dikunjungi. Dengan data tersebut, sistem memeriksa apakah artikel tersedia atau tidak. Jika tersedia sistem akan melanjutkan proses dan jika tidak user akan ditujukan pada halaman utama. Kemudian sistem akan mencatat kunjungan tersebut dan melakukan proses kalkulasi rekomendasi artikel dari data catatan kunjungan yang telah terkumpul. Pada proses kalkuasi rekomendasi artikel, algoritma Apriori digunakan untuk mencari itemset frekuen dan pembentukan aturan asosiasi. Rekomendasi artikel dihasilkan dari aturan asosiasi yang terbentuk oleh algoritma Apriori. Sebelum menampilkan hasil, sistem akan memeriksa apakah jumlah rekomendasi artikel telah memenuhi kebutuhan dan jika tidak maka diambil artikel secara acak untuk melengkapi kekurangan.

\section{b. Sequence Diagram}

Sequence diagram merupakan suatu diagram yang menggambarkan komunikasi antar objek yang ada dalam website yang akan dikembangkan. Diagram ini menunjukkan urutan interaksi yang dilakukan oleh objek didalam suatu website.

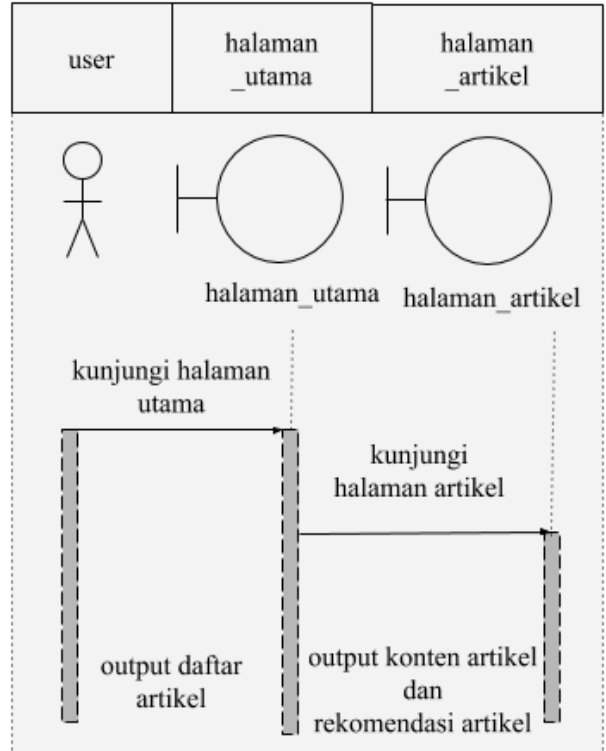

Gambar 3 Sequence Diagram Mengunjungi Halaman Artikel

Sequence diagram yang ditujukan pada Gambar 3 merupakan proses rekomendasi artikel. Langkah-langkahnya user mengunjungi halaman utama kemudian user mengunjungi artikel yang disediakan. Setelah itu, sistem akan mencatat kunjungan artikel dan melakukan kalkulasi rekomendasi artikel. Pada proses kalkuasi rekomendasi artikel, algoritma Apriori digunakan untuk mencari itemset frekuen dan pembentukan aturan asosiasi. Rekomendasi artikel dihasilkan dari aturan asosiasi yang terbentuk oleh algoritma Apriori. Selanjutnya user akan mendapatkan halaman artikel yang berisi rekomendasi artikel.

\section{Perancangan Database}

Database merupakan data-data yang terdiri dari sebuah tabel yang memiliki hubungan dengan tabel lain. Fungsi database yaitu menampung beberapa tabel dan query yang digunakan untuk mengolah data. Dalam pembuatan dan mengakses database dapat menggunakan banyak cara, tetapi yang dirancang dalam website ini menggunakan database mysql karena tampilan database dapat dibuat sesuai dengan keinginan perancang. Dapat dilihat perancangan tabel dari database yang akan dibuat yaitu database u217585741_mydb. 


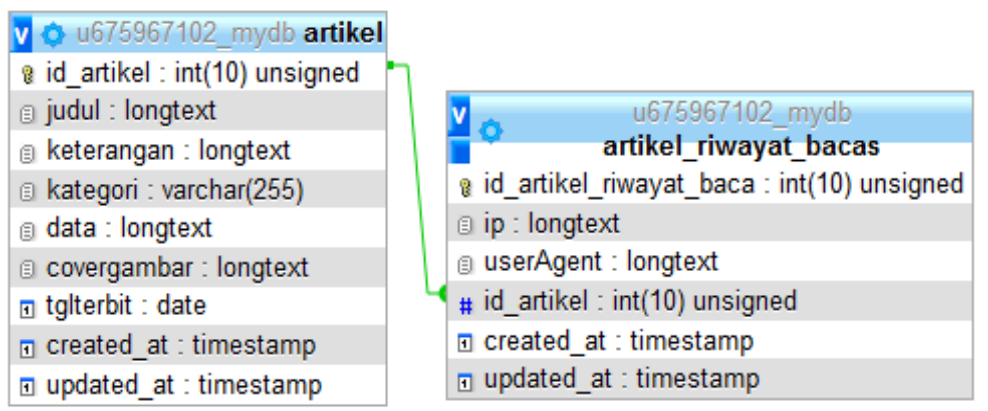

Gambar 4 Relasi Database Rekomendasi Artikel Website Art7wing

\section{Perancangan Interface}

Interface website ini dirancang dengan tujuan mempermudah dalam pengoperasian dan membuat interakasi sederhana serta efisien dalam menarik perhatian pengunjung. Dan menyeimbangkan antara fungsi teknis dan elemen visual agar dapat beroperasi sesuai tujuan.

\section{Pengumpulan Bahan}

Tahap ini adalah tahap pengumpulan semua bahan yang berhubungan dengan proses pengembangan website, baik berupa file gambar, teks dan beberapa sumber dibuat sendiri dengan menggunakan software pendukung dan juga sebagian diperoleh dari beberapa sumber di internet.

\section{Perakitan}

Tahap assembly atau perakitan merupakan tahap merakit bahan-bahan yang dibutuhkan dalam mengembamgkan website sehingga menjadi website yang memiliki komponen mekanisme algoritma Apriori untuk memberikan rekomendasi artikel. Bahasa pemrograman yang digunakan untuk implementasi algoritma Apriori untuk memberikan rekomendasi artikel di dalam perakitan ini menggunakan bahasa pemrograman PHP. Kemudian bahasa pemrograman ini digunakan sebagai pengolah data riwayat kunjungan menjadi rekomendasi artikel.

\section{Distribusi}

Setelah aplikasi web jadi maka proses distribusi ini meliputi proses upload ke virtual server. Penyimpanan website dalam bentuk folder dan file, dengan berbagai bentuk hak akses untuk menjaga keamanan dan pengembangan website.

\section{Hasil Algoritma Apriori terhadap Rekomendasi Artikel}

Algoritma Apriori pada website yang dikembangkan, yaitu algoritma Apriori untuk menghasilkan rekomendasi artikel. Hasil penerapan algoritma Apriori bisa terlihat saat mengunjungi halaman artikel dan mencocokkan hasil rekomendasi artikel dengan hasil analisis algoritma Apriori.

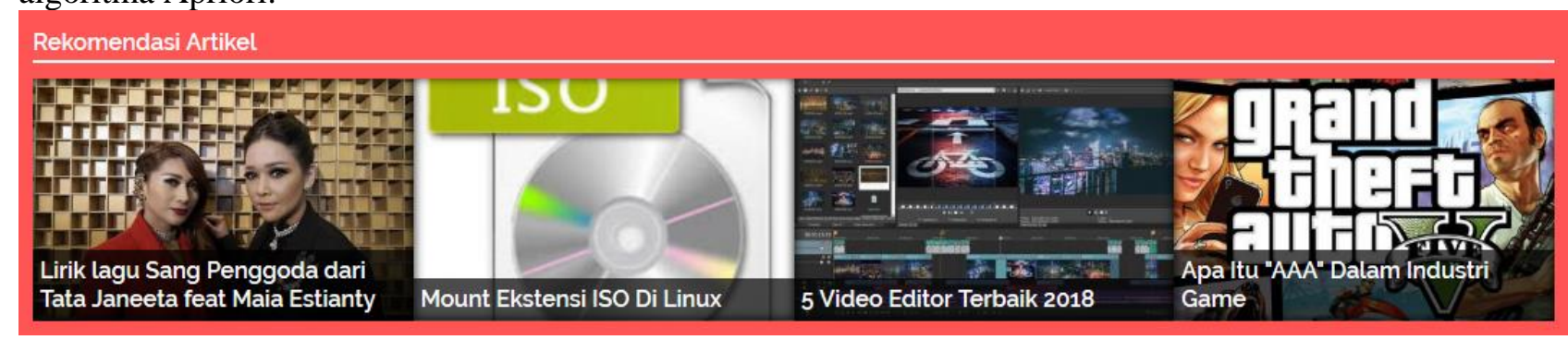

Gambar 5 Rekomendasi Artikel Pada Halaman Artikel Kategori News

Misalkan menguji dengan mengunjungi artikel dengan kategori News, maka rekomendasi artikel yang ditampilkan seperti tampak pada Gambar 5. Terlihat bahwa kategori item rekomendasi artikel yang ditamplikan, yaitu Musik, Linux, dan Komputer. Setelah itu, mencocokkan hasil rekomendasi artikel tersebut dengan hasil analisis algoritma Apriori. Dengan melihat hasil analisis algoritma Apriori, diketahui bahwa kategori item rekomendasi artikel diambil dari antecedent aturan asosiasi "Jika Musik, Linux, dan Komputer, maka News" yang terbentuk dari calon aturan asosiasi dari $F_{4}$ seperti tampak pada Tabel 8. Aturan 
asosiasi yang digunakan merupakan aturan asosiasi yang terakhir disimpan dan memiliki nilai consequent sama dengan kategori artikel yang dikunjungi. Kategori item artikel diambil secara acak yang dipublis selama 3 bulan sesuai dengan kategori artikel pada antecedent aturan asosiasi terpilih.

Tabel 8 Calon Aturan Asosiasi dari F4

\begin{tabular}{lc}
\hline \multicolumn{1}{c}{ Calon Aturan Asosiasi } & Confidence \\
\hline Jika Musik, Linux, dan Komputer, maka News & $31 / 31100 \%$ \\
\hline Jika News, Linux, dan Komputer, maka Musik & $31 / 3783.783783783784 \%$ \\
\hline Jika News, Musik, dan Komputer, maka Linux & $31 / 5457.407407407407 \%$ \\
\hline Jika News, Musik, dan Linux, maka Komputer & $31 / 4864.583333333333 \%$ \\
\hline
\end{tabular}

\section{PENUTUP}

\section{Kesimpulan}

Berdasarkan hasil pengujian dapat disimpulkan bahwa aturan asosiasi "Jika Musik, Linux, dan Komputer, maka News" dengan nilai confidence $100 \%$ yang dibentuk algoritma Apriori digunakan untuk memberi-kan rekomendasi artikel pada halaman artikel dengan kategori News. Kunjungan ke halaman artikel dapat mempengaruhi aturan asosiasi yang terbentuk dari algoritma Apriori. Pada tahap analisa frekuensi tertingi, kategori item artikel dari data riwayat kunjungan untuk mencari itemset frekuen. Kemudian pada tahap pembentukan aturan asosiasi, dilakukan pembentukan aturan asosiasi dari itemset frekuen yang telah ditemukan. Aturan asosiasi yang digunakan untuk rekomendasi artikel yaitu aturan asosiasi yang terakhir disimpan dan memiliki nilai consequent sama dengan kategori artikel yang dikunjungi. Rekomendasi artikel berhasil ditampilkan pada halaman artikel website Art7wing.

\section{Saran}

Penelitian lanjutan perlu dilakukan pengembangan dalam penetapan minimum support dan minimum confidence secara otomatis dengan mengolah data dari hasil yang didapat sebelumnya secara berkala, sehingga aturan asosiasi yang dibentuk lebih akurat.

\section{DAFTAR PUSTAKA}

[1.] Binanto, Iwan., 2013, Perbandingan Metode Pengembangan Perangkat Lunak Multimedia, Seminar Nasional RITEKTRA: 153-160, Jakarta.

[2.] Fadlina, 2014, Data Mining Untuk Analisa Tingkat Kejahatan Jalanan Dengan Algoritma Association Rule Metode Apriori, Jurnal Ilmiah Informasidan Tekhnologi Ilmiah, Vol. 3, No.1.

[3.] Kusrini dan Luthfi, E.T., 2013, Algoritma Data Mining, Yogyakarta: ANDI.

[4.] Sugiyono., 2016, Metode Penelitian Kuantitatif, Kualitatif dan R\&D, Bandung: PT Alfabet.

[5.] Sutopo, A.H., 2012, Teknologi Informasi dan Komunikasi dalam Pendidikan, Yogyakarta: Graha Ilmu

[6.] Trimarsiah, Y., dan M. Arafat., 2017, Analisis Dan Perancangan Website Sebagai Sarana Informasi Pada Lembaga Bahasa Kewirausahaan Dan Komputer Akmi Baturaja, Jurnal Ilmiah MATRIK, Vol. 19, No.1, 1-10. 